\title{
The Anti-inflammatory Mechanism of Protaetia brevitarsis Lewis via Suppression the Activation of NF-KB and Caspase-1 in LPS-stimulated RAW264.7 Cells
}

\author{
Noh-Yil Myung ${ }^{1, *}$, Eun-Mi Ahn ${ }^{2, *}$ and Su-Jin Kim", ${ }^{2, *}$ \\ ${ }^{I}$ Department of Oriental Medicine and Healthcare, Wonkwang Digital University, Iksan, Jeonbuk 54538, Korea \\ ${ }^{2}$ Department of Biotechnology and Convergence, Daegu Haany University, Kyungsan 38578, Korea
}

The larva of Protaetia brevitarsis Lewis (P. brevitarsis), edible insect, is traditionally consumed as alternative source of nutrients and has various health benefits. However, the exact pharmaceutical effects of $P$. brevitarsis on inflammatory response are still not well understood. Thus, we investigated the anti-inflammatory effects and mechanisms of $P$. brevitarsis in lipopolysaccharide (LPS)-stimulated RAW264.7 cells. We investigated the effects of P. brevitarsis on the expression levels of inflammatory-related genes, including inflammatory cytokines, prostaglandin $\mathrm{E}_{2}\left(\mathrm{PGE}_{2}\right)$, cyclooxygenase $(\mathrm{COX})-2$ and inducible nitric oxide synthase (iNOS) in LPS-stimulated RAW264.7 cells. To understand the anti-inflammatory mechanism of $P$. brevitarsis, we explored the regulatory effect of $P$. brevitarsis on nuclear factor (NF)-kB and caspase-1 activation. The findings of this study demonstrated that $P$. brevitarsis inhibits the LPS-induced inflammatory cytokine and $\mathrm{PGE}_{2}$ levels, as well as COX-2 and iNOS expression. Moreover, we confirmed that the anti-inflammatory effect of $P$. brevitarsis occurs via suppression of the activation of NF- $\mathrm{kB}$ and caspase-1. Conclusively, these findings provide experimental evidence that $P$. brevitarsis may be useful candidate for the treatment of inflammatory-related diseases.

Key Words: Protaetia brevitarsis Lewis; Inflammation; Nuclear factor-kappa B; Caspase-1

\section{INTRODUCTION}

Edible insects have received a revived interest as healthy nutritious source or traditional remedies for various diseases, including anemia, hypertension and asthma (Van Itterbeeck and van Huis, 2012; Van Huis, 2016). Although edible insects have long been employed in effective treatment of diseases, their precise pharmaceutical mechanisms are still not well understood.

Inflammatory diseases, including allergic rhinitis, asthma Crohn's disease and rheumatoid arthritis, have become a global health problem. Generally, inflammatory processes are involved in the action of multiple factors within a complex network (Guo et al., 2015). Although inflammatory reactions are considered an important response to host defense against pathogens, prolonged inflammation can lead to various chronic diseases. Activated macrophages induce variety of inflammatory mediators, such as tumor necrosis factor (TNF)- $\alpha$, interleukin (IL)- 6 , cyclooxygenase (COX)-2 and inducible nitric oxide synthase (iNOS), which play crucial role in the process of inflammation (Liu et al., 2014). The increase in inflammatory mediators may be important in the development of chronic inflammatory diseases (Wicks

Received: November 15, 2020 / Revised: December 5, 2020 / Accepted: December 8, 2020

* Professor.

$\dagger$ Corresponding author: Su-Jin Kim. Department of Biotechnology and Convergence, Daegu Haany University, Kyungsan 38578 , Korea. Tel: +82-53-819-1389, Fax:+82-53-819-13898, e-mail: ksj1009@dhu.ac.kr

(C) The Korean Society for Biomedical Laboratory Sciences. All rights reserved.

(C) This is an Open Access article distributed under the terms of the Creative Commons Attribution Non-Commercial License (http://creativecommons.org/licenses/by-nc/3.0/) which permits unrestricted non-commercial use, distribution, and reproduction in any medium, provided the original work is properly cited. 
and Roberts, 2016). Therefore, the suppression of inflammatory mediator release by macrophage is a useful therapeutic strategy for inflammation-related diseases.

Nuclear factor-kappa B (NF- $\kappa \mathrm{B})$ performs an important function in the expression of genes associated with the inflammatory responses (Lee et al., 2020). In response to inflammatory stimuli, the IKB kinase (IKK) complex is phosphorylated and the I $\mathrm{KB}$ is degraded, allowing free NF$\kappa \mathrm{B}$ to translocate into the nucleus, modulate gene transcription, and activate various inflammatory mediators. An increased NF- $\kappa \mathrm{B}$ activity has been reported in macrophages and epithelial cells of patients with inflammatory diseases (Wong et al., 2001). Moreover, inhibition of NF-kB activation diminishes the influx of inflammatory cells and reduces the allergic inflammation (Birrell et al., 2005). Therefore, $\mathrm{NF}-\mathrm{\kappa B}$ is currently considerd to be a target for the treatment of inflammatory diseases.

Protaetia brevitarsis Lewis (P. brevitarsis) is a species of Coleoptera, and the larvae stage of $P$. brevitarsis has been used as a traditional medicine for various diseases (Yoo et al., 2007). Our previous study showed that $P$. brevitarsis has the anti-obesity activity through the inhibition of body weight gain, serum lipid levels, peritoneal fat and obesityrelated gene expression (Ahn et al., 2019). However, the exact anti-inflammatory mechanism of $P$. brevitarsis is still not well understood. To provide experimental evidence that $P$. brevitarsis might be a useful therapeutic drug for inflammatory diseases, we investigated the effects of $P$. brevitarsis on the expression of inflammatory mediators, as well as activation of NF- $\mathrm{KB}$ and caspase-1 in lipopolysaccharide (LPS)-induced RAW264.7 cells.

\section{MATERIALS AND METHODS}

\section{Reagents}

LPS, 3-(4,5-dimethylthiazol-2-yl)-diphenyl-tetrazoliumbromide (MTT), avidin peroxidase (AP), and other reagents were purchased from Sigma-Aldrich (St. Louis, MO, USA). Enhanced chemiluminescence (ECL) kits were obtained from Thermo Fisher Scientific Inc. (Somerset, NJ, USA). Dulbecco's Modified Eagle's Medium (DMEM) was obtained from Difco Laboratories (Detroit, MI, USA). The assay kits for mouse TNF- $\alpha$ / IL-6/ IL-1 $\beta$ were procured from BD Biosciences (San Diego, CA, USA). Caspase-1 assay kit were obtained from Biovision (Milpitas, CA, USA). The specific antibodies $(\mathrm{Ab})$ against $\mathrm{COX}-2$, iNOS, NF- $\kappa \mathrm{B}$, and histone were procured from Santa Cruz Biotechnology (CA, USA).

\section{Preparation of $\boldsymbol{P}$. brevitarsis}

P. brevitarsis (100 g) was pulverized into fine powder and $500 \mathrm{~mL}$ of $70 \%$ aqueous ethanol solution was used for extraction for $24 \mathrm{~h}$ and then concentrated under vacuum. The ethanol extract was filtered, concentrated, and lyophilized (yield: $8.42 \%$ ). The samples were dissolved in PBS, and then filtered through $0.22-\mu \mathrm{m}$ syringe filter.

\section{Cell culture}

RAW264.7 cells were cultured in DMEM containing with penicillin $(100 \mathrm{IU} / \mathrm{mL})$, streptomycin $(100 \mu \mathrm{g} / \mathrm{mL})$, and $10 \%$ FBS at $37^{\circ} \mathrm{C}$ in in a humidified atmosphere of $5 \% \mathrm{CO}_{2}$.

\section{MTT assay}

To investigate the cell viability by $P$. brevitarsis, the MTT assay was conducted. Briefly, cells were incubated with $P$. brevitarsis $(0.01,0.5$, and $1 \mathrm{mg} / \mathrm{mL})$ for $24 \mathrm{~h}$, and $50 \mu \mathrm{L}$ of MTT solution was added and the mixture was incubated for $4 \mathrm{~h}$. Then, the crystallized formazan was dissolved in dimethyl sulfoxide and the absorbance of plate was read at $540 \mathrm{~nm}$ using a microplate reader (Molecular Devices, CA, USA).

\section{Cytokine assay}

The levels of TNF- $\alpha$ / IL-6/ IL-1 $\beta$ were assayed by using a modification of an enzyme-linked immunosorbent assay (ELISA), as previously described (Kim et al., 2010). Briefly, plates (96-well) were coated with TNF- $\alpha$ / IL-6/ IL-1 $\beta$ monoclonal $\mathrm{Abs}$ and then incubated overnight at $4{ }^{\circ} \mathrm{C}$. After washes, standard solution of TNF- $\alpha /$ IL-6/ IL-1 $\beta$ or sample were added and incubated for $2 \mathrm{~h}$. The plate was exposed to biotinylated TNF- $\alpha$ / IL-6/ IL-1 $\beta$ Abs followed by incubation for $2 \mathrm{~h}$. After washing the plates, AP and ABTS substrate was sequentially added. The optical density was read at $405 \mathrm{~nm}$. 


\section{$\mathrm{PGE}_{2}$ assay}

The $\mathrm{PGE}_{2}$ concentration in cell culture supernatant was measured using $\mathrm{PGE}_{2}$ colorimetric assay kit (R\&D Systems, Minneapolis, MN, USA) following the manufacturer's protocols.

\section{Measurement of nitrite (NO) concentration}

RAW264.7 cells $\left(3 \times 10^{5}\right.$ cells/well) were treated with $P$. brevitarsis for $1 \mathrm{~h}$, and then stimulated with LPS $(1 \mu \mathrm{g} / \mathrm{mL})$ for $24 \mathrm{~h}$. The NO content was determined using Griess reagent. The supernatant of cell culture was mixed with an equal volume of griess reagent. The optical density was measured at $540 \mathrm{~nm}$. The NO concentration was measured by a standard curve generated using sodium nitrite.

\section{Western blot analysis}

To investigate the protein levels, cells were lysed using icecold lysis buffer. Nuclear extracts were isolated by Nuclear Extraction Reagents. After protein quantification using bicinchoninic acid (BCA), the lysed protein was mixed with a sample buffer, separated using gel electrophoresis, and transferred to membrane. The membrane was then blocked with $5 \%$ skimmed milk and reacted with primary Abs. After washing with $0.1 \%$ PBST, membrane was incubated with secondary Abs for $2 \mathrm{~h}$. After washing with PBST, the protein bands were visualized by an ECL detection system.

\section{Luciferase reporter gene assay}

RAW264.7 cells were transfected with NF- $\kappa B-l u c$ DNA and the medium was refreshed. The transfected cells were seeded and treated with $P$. brevitarsis for $1 \mathrm{~h}$ and stimulated with LPS for $2 \mathrm{~h}$. Luciferase activity was measured using a Dual-Glo luciferase assay kit following the manufacturer's protocols (Promega, Madison, Wisconsin, USA).

\section{Caspase-1 activity assay}

The caspase- 1 activity was measured using a caspase-1 colorimetric assay kit according to the manufacturer's instructions. The lysed cells were centrifuged at 12,000 rpm for $10 \mathrm{~min}$. After protein quantification by BCA, the protein was incubated with $50 \mu \mathrm{L}$ reaction buffer and $5 \mu \mathrm{L}$ caspase- 1 substrates at $37^{\circ} \mathrm{C}$ for $2 \mathrm{~h}$. The absorbance was measured at $405 \mathrm{~nm}$.

\section{Statistical analysis}

Results are shown as the mean $\pm \mathrm{SD}$, and each experiment was performed at least-three times. The statistical results were performed using an independent $t$-test and ANOVA with a Tukey post hoc test. $P<0.05$ was considered statistically significant.

\section{RESULTS}

Effects of $P$. brevitarsis on cell viability and production of inflammatory cytokines in LPS-stimulated RAW264.7 cells

We evaluated the cytotoxic effects of $P$. brevitarsis after treatment with various concentrations of $P$. brevitarsis $(0.01$, 0.5 , and $1 \mathrm{mg} / \mathrm{mL}$ ) for $24 \mathrm{~h}$ using an MTT assay. In present study, no cell cytotoxicity of $P$. brevitarsis was observed (Fig. 1A). Next, to investigate the anti-inflammatory activity of $P$. brevitarsis, we evaluated the effects of $P$. brevitarsis on TNF- $\alpha$, IL- 6 and IL- $1 \beta$ production from LPS-stimulated RAW 264.7 cells. The cells were treated with or without $P$. brevitarsis $(0.01,0.5$ and $1 \mathrm{mg} / \mathrm{mL}$ ) for $1 \mathrm{~h}$ prior to stimulation with LPS for $24 \mathrm{~h}$. As shown in Fig. 1B and D, LPS alone increased TNF- $\alpha$, IL- 6 , and IL- $1 \beta$ production compared to the LPS-untreated control. However, treatment with P. brevitarsis significantly inhibited LPS-induced TNF- $\alpha$, IL-6 and IL-1 $\beta$ production in a dose-dependent manner. The maximal inhibition rates of TNF- $\alpha$, IL- 6 , and IL-1 $\beta$ production by $P$. brevitarsis $(1 \mathrm{mg} / \mathrm{mL})$ were approximately 40.1\% $(P<0.05), 33.7 \%(P<0.05)$ and $29.5 \%(P<0.05)$, respectively.

\section{Effects of $P$. brevitarsis on COX-2 expression and $\mathrm{PGE}_{2}$ production in LPS- stimulated RAW264.7 cells}

Increase of COX-2 levels are associated with physiological processes of inflammation (Liu et al., 2018). Western blot analysis was conducted to measure the effects of $P$. brevitarsis on LPS-induced COX-2 expression. The cells were treated for $1 \mathrm{~h}$ with $P$. brevitarsis $(0.01,0.5$ and $1 \mathrm{mg}$ / $\mathrm{mL}$ ) and stimulated for $24 \mathrm{~h}$ with LPS. As shown in Fig. 2A, 
(A)

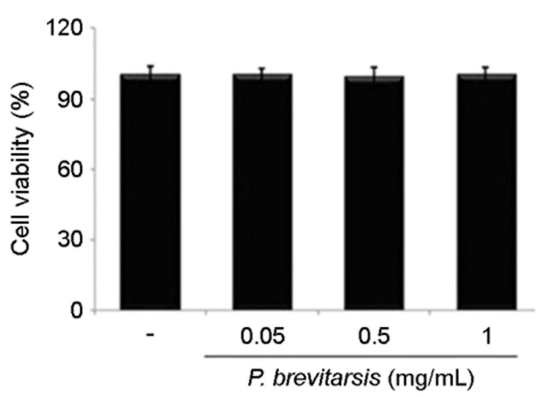

C

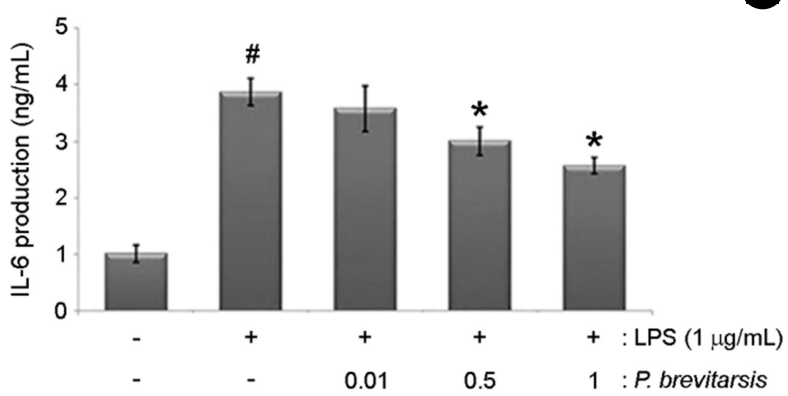

(D)
B
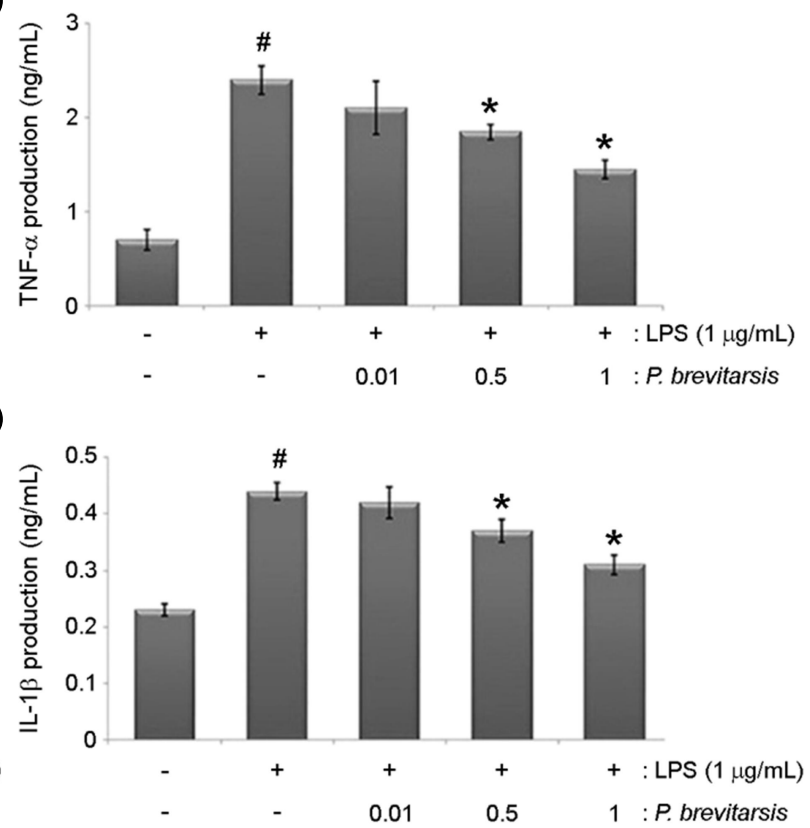

Fig. 1. Effects of $P$. brevitarsis on cell viability and production of inflammatory cytokines in LPS-induced RAW264.7 cells. Cells (3 $\times 10^{5}$ cells $/ \mathrm{mL}$ ) were treated for $1 \mathrm{~h}$ with $P$. brevitarsis $(0.1,0.5$ and $1 \mathrm{mg} / \mathrm{mL})$, and stimulated with LPS $(1 \mu \mathrm{g} / \mathrm{mL})$ for $24 \mathrm{~h}$. (A) Cell viability was analyzed by MTT assay. (B-D) The levels of TNF- $\alpha$, IL- 6 and IL-1 $\beta$ in the supernatant were measured using ELISA. The results are presented as mean $\pm \operatorname{SD}\left({ }^{\sharp} P<0.05\right.$ vs. control, ${ }^{*} P<0.05$ vs. LPS alone).

A

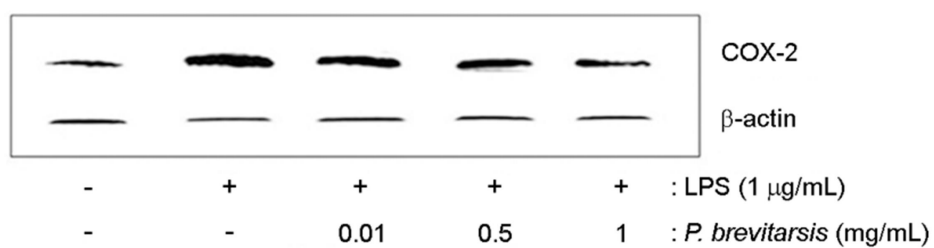

B

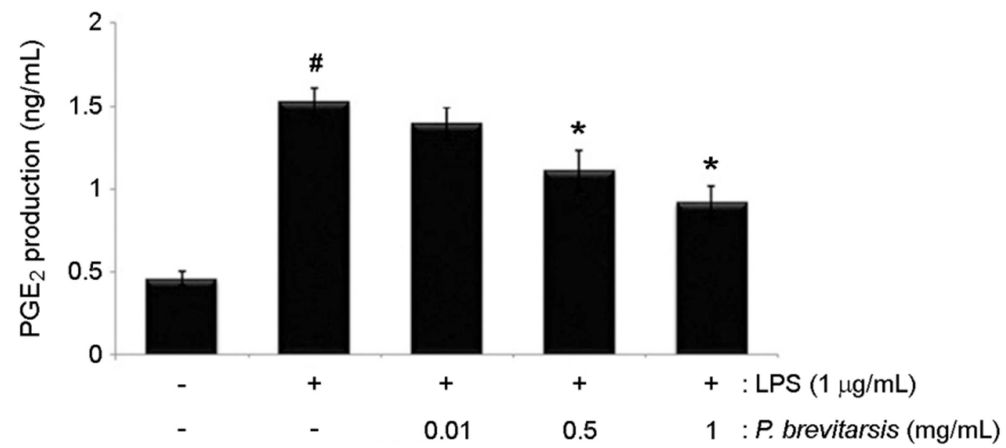

Fig. 2. Effects of $P$. brevitarsis on COX-2 and PGE, levels in LPS-induced RAW264.7 cells. (A) Cells $\left(1 \times 10^{6}\right.$ cells $\left./ \mathrm{mL}\right)$ treated for $1 \mathrm{~h}$ with $P$. brevitarsis $(0.1,0.5$, and $1 \mathrm{mg} / \mathrm{mL})$ and stimulated with LPS $(1 \mu \mathrm{g} / \mathrm{mL})$ for $24 \mathrm{~h}$. The protein extracts were assayed via Western blot analysis for COX-2 (B) Cells were pretreated for $1 \mathrm{~h}$ with $P$. brevitarsis $(0.1,0.5$ and $1 \mathrm{mg} / \mathrm{mL})$ and stimulated for $24 \mathrm{~h}$ with LPS $(1 \mu \mathrm{g} / \mathrm{mL})$. The levels of $\mathrm{PGE}_{2}$ production was evaluated with assay kit. The results are presented as mean \pm SD $\left({ }^{\sharp} P<0.05\right.$ vs. control, ${ }^{*} P<0.05$ vs. LPS alone).
LPS induced the expression of COX-2, but $P$. brevitarsis inhibited the LPS-induced the COX-2 levels.

COX-2 catalyzes the biosynthesis of $\mathrm{PGE}_{2}$, which contributes to the pain and swelling during inflammatory pro- cess (Rumzhum and Ammit, 2016). Thus, we examined the regulatory effect of $P$. brevitarsis on $\mathrm{PGE}_{2}$ production in LPS-stimulated RAW264.7 cells. As shown in Fig. 2B, $\mathrm{PGE}_{2}$ production was enhanced in response to LPS treatment; 
however, this increase was significantly suppressed by $P$. brevitarsis treatment. The maximal inhibition rate of $\mathrm{PGE}_{2}$ production by $P$. brevitarsis $(1 \mathrm{mg} / \mathrm{mL})$ was approximately 40.4\% $(P<0.05)$.

\section{Effects of $P$. brevitarsis on the NO and iNOS levels in LPS- stimulated RAW264.7 cells}

As a NO increase is associated with inflammatory process, we investigated the effects of $P$. brevitarsis on NO production using Griess reagent. P. brevitarsis was shown to induce a reduction in $\mathrm{NO}$ production in a dose-dependent manner (Fig. 3A), with a maximal inhibition rate of NO production by $P$. brevitarsis $(1 \mathrm{mg} / \mathrm{mL})$ being measured as $38.9 \%(P<0.05)$. Additionally, Western blot analysis was conducted to measure the effect of $P$. brevitarsis on LPSinduced iNOS expression. As shown in Fig. 3B, LPS induced a increase in iNOS expression, but the level of iNOS decreased, in response to treatment with $P$. brevitarsis.

\section{Effects of $P$. brevitarsis on NF-кB activation in LPS- stimulated RAW264.7 cells}

As suppression of NF- $\kappa \mathrm{B}$ activation was identified as an anti-inflammatory strategy, we theorized that the antiinflammatory mechanism of $P$. brevitarsis may be mediated via the attenuation of NF- $\mathrm{BB}$ activation. Because NF- $\kappa \mathrm{B}$ activation generally requires the translocation of NF- $\mathrm{KB}$ into nuclear, we elucidated the effects of $P$. brevitarsis on the nuclear and cytosolic pools of NF- $\mathrm{kB}$ using Western blot
A

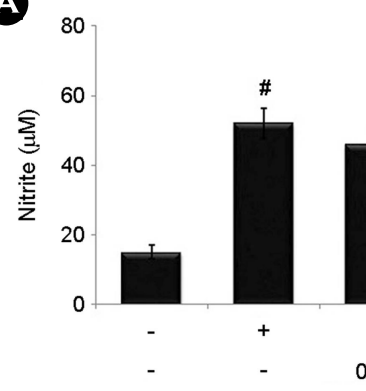

B

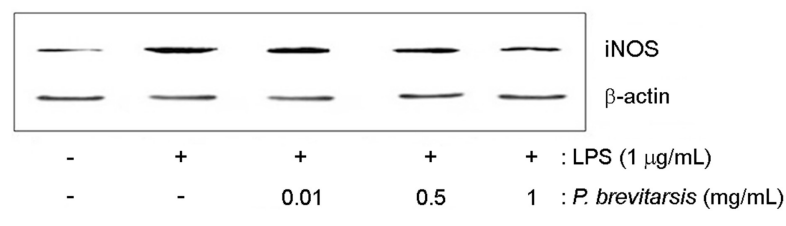

Fig. 3. Effects of $P$. brevitarsis on NO and iNOS levels in LPS-induced RAW264.7 cells. Cells were treated for $1 \mathrm{~h}$ with $P$. brevitarsis $(0.1,0.5$ and $1 \mathrm{mg} / \mathrm{mL})$ followed by LPS $(1 \mu \mathrm{g} / \mathrm{mL})$ for $24 \mathrm{~h}$. (A) NO production in supernatant was measured via the Griess reagent. (B) The protein extract was assayed via Western blot analysis for iNOS. The results are presented as mean $\pm \mathrm{SD}\left({ }^{\sharp} P<0.05\right.$ vs. control, ${ }^{*} P<$ 0.05 vs. LPS alone).

A

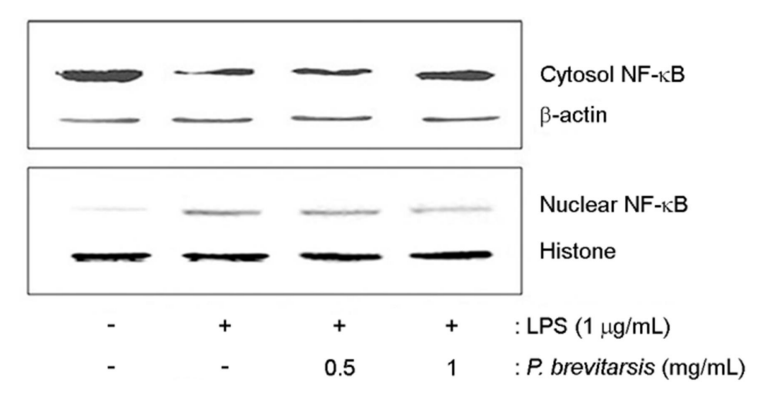

B

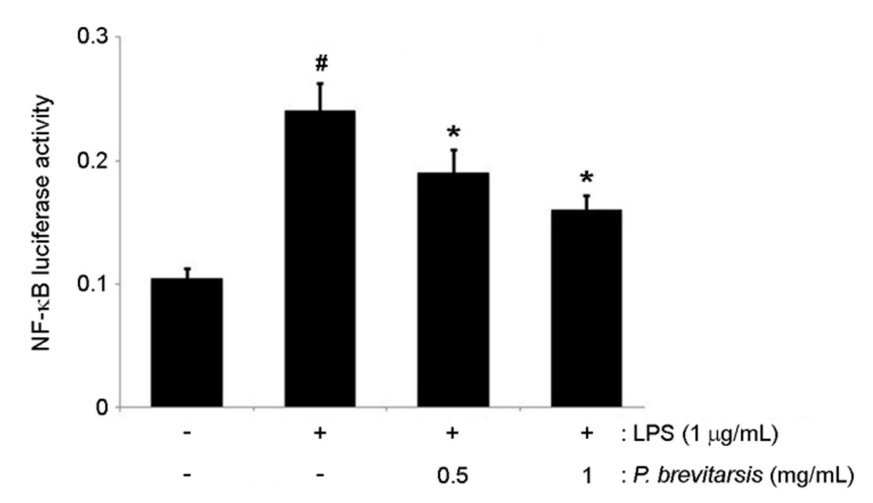

Fig. 4. Effect of $\boldsymbol{P}$. brevitarsis on NF-אB activation in LPS-stimulated RAW264.7 cells. (A) Cells $\left(1 \times 10^{6}\right.$ cells $\left./ \mathrm{mL}\right)$ were treated for 1 $\mathrm{h}$ with $P$. brevitarsis and stimulated for $2 \mathrm{~h}$ with LPS. Nuclear extracts were prepared by Nuclear Extraction Reagents and evaluated for NF- $\mathrm{kB}$ via Western blot analysis. (B) The activity was measured by a luciferase assay kit following the manufacturer's protocols. The results are presented as mean $\pm \mathrm{SD}\left({ }^{\sharp} P<0.05\right.$ vs. control, ${ }^{*} P<0.05$ vs. LPS alone $)$. 


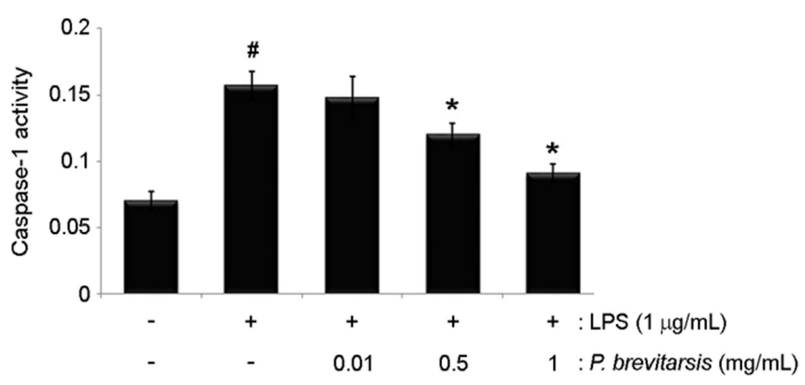

Fig. 5. Effect of $P$. brevitarsis on caspase-1 activity in LPSinduced RAW264.7 cells. The cells were treated with P. brevitarsis $(0.1,0.5$ and $1 \mathrm{mg} / \mathrm{mL})$ for $1 \mathrm{~h}$ and stimulated with LPS for $12 \mathrm{~h}$. Caspase-1 activity was determined using a caspase-1 colorimetric assay. The results are presented as mean \pm SD $\left({ }^{\sharp} P<0.05\right.$ vs. control, ${ }^{*} P<0.05$ vs. LPS alone).

analysis. The levels of NF-kB (Rel/p65) in the nuclear fraction were increased in LPS-stimulated cells, but $P$. brevitarsis reduced the enhanced nuclear levels of Rel/p65 (Fig. 4A). Moreover, to measure the effect of $P$. brevitarsis on the promoter activity of $\mathrm{NF}-\mathrm{kB}$, a luciferase reporter assay was conducted. As illustrated in Fig. 4B, P. brevitarsis attenuated the NF- $\kappa \mathrm{B}$-driven luciferase activity in LPS-induced RAW 264.7 cells.

\section{Effect of $P$. brevitarsis on caspase-1 activation in LPS- stimulated RAW264.7 cells}

Caspase-1 activation is associated with inflammatory reaction by causing an increase in inflammatory cytokines and in the recruitment of inflammatory cells (Han et al., 2017). Therefore, to identify the regulatory mechanism of $P$. brevitarsis in inflammation, we assessed whether $P$. brevitarsis inhibits the caspase-1 activity in LPS-stimulated cells. The results showed that LPS treatment induced the caspase- 1 activation but, the increase in caspase-1 activity was down-regulated by $P$. brevitarsis in a dose-dependent manner (Fig. 5). The maximal inhibition rate of caspase-1 activity by $P$. brevitarsis $(1 \mathrm{mg} / \mathrm{mL})$ was approximately $45.8 \%(P<0.05)$.

\section{DISCUSSION}

Edible insects have been widely used, since they are healthy nutritious source and can be used in traditional medicine. Although P. brevitarsis demonstrated various biological activities, the precise anti-inflammatory mechanisms of $P$. brevitarsis have yet to be thoroughly elucidated. The findings of this study show that $P$. brevitarsis inhibited the levels of TNF- $\alpha$, IL-1 $\beta, \mathrm{NO}$, and $\mathrm{PGE}_{2}$ as well as the expression of COX-2 and iNOS. Moreover, we confirmed that the anti-inflammatory effect of $P$. brevitarsis is mediated via the suppression the activation of NF- $\kappa \mathrm{B}$ and caspase-1 in LPS-stimulated RAW264.7 cells. These results suggest a molecular mechanism via which $P$. brevitarsis ameliorates the inflammatory reaction.

Inflammatory processes are biological response of the immune system that can be induced by a variety of factors including pathogens, injury, and toxic compounds (Edwards et al., 2017). Macrophages actively contribute to inflammatory responses by releasing inflammatory mediators (Beutler, 2000). In response to stimuli, macrophages generate a variety of inflammatory cytokines that contribute to the infiltration of immune cells to inflammation sites (Trefzer et al., 2003). It has also been reported that TNF- $\alpha$ and IL-6 levels are increased in patients with inflammatory diseases (Fedenko et al., 2011). $\mathrm{PGE}_{2}$, produced by COX-2 at inflammatory sites, contributes to the pain and swelling, which are associated with inflammation (Liu et al., 2018). These results suggest that suppression of inflammatory mediators from activated macrophages is a useful therapeutic strategy for treatment of inflammatory diseases. Therefore, we investigated whether the anti-inflammatory activity of $P$. brevitarsis is mediated by the attenuation of inflammatory mediators, such as inflammatory cytokines, $\mathrm{COX}-2, \mathrm{PGE}_{2}$ and $\mathrm{NO}$ in LPS-simulated RAW 264.7 cells. In this study, we showed that $P$. brevitarsis significantly suppressed the LPS-induced production of inflammatory cytokines (TNF- $\alpha$, IL-6, and IL$1 \beta$ ) and mediators ( $\mathrm{PGE}_{2}, \mathrm{COX}-2, \mathrm{NO}$ and $\left.\mathrm{iNOS}\right)$. Based on these results, we propose that the anti-inflammatory activity of $P$. brevitarsis may be associated with the suppression of inflammatory-related gene expression.

Accumulating evidence suggests that the NF- $\kappa B$ performs a crucial function by regulation the transcription of numerous genes involved in inflammation (Shin et al., 2019). An increased NF- $\kappa B$ activity associated with the secretion of IL- 6 and TNF- $\alpha$ was shown to be involved in inflammatory 
diseases (Sultuybek et al., 2019). It was reported that inhibition of NF- $\kappa$ B activation reduced the influx of inflammatory cells and diminished the inflammation (Birrell et al., 2005). Caspase-1 plays an important role in apoptosis and inflammation (Siegmund et al., 2001). Caspase-1 activation is associated with an increased number of inflammatory mediators. It was been reported that caspase-1- deficiency mice have a reduced cytokine production (Kuida et al., 1995). Additionally, it was confirmed that activation of caspasse-1 induced NF- $\kappa \mathrm{B}$ and MAPK-signaling pathways. Based on these results, the suppression of NF- $\kappa \mathrm{B} /$ caspase1 activation was identified as an anti-inflammatory strategy. Therefore, to investigate the anti-inflammatory mechanism of $P$. brevitarsis, we tested whether $P$. brevitarsis could ameliorate the NF- $\mathrm{\kappa B} /$ caspase-1 activation. The results demonstrated that $P$. brevitarsis inhibits NF- $\mathrm{BB}$ translocation into the nucleus and caspase-1 activation. We hypothesized that inhibitory effects of $P$. brevitarsis on inflammation might derive from the blockage of NF- $\mathrm{BB} /$ caspase-1 activity in LPS-stimulated RAW 264.7 cells.

In conclusion, our results suggest that the anti-inflammatory activities of $P$. brevitarsis could be attributed to the suppression of inflammatory mediators. Moreover, the antiinflammatory mechanism of $P$. brevitarsis is caused by the attenuation of LPS-induced NF- $\kappa \mathrm{B} /$ caspase-1 activation. Our results provide experimental evidences that $P$. brevitarsis may be a potential candidate for the treatment of inflammatoryrelated diseases.

\section{ACKNOWLEDGEMENT}

This research was supported by Basic Science Research Program through the National Research Foundation of Korea (NRF) funded by the Ministry of Education (NRF 2017R1D1A1B03031186 and NRF - 2018R1C1B5083153).

\section{CONFLICT OF INTEREST}

There is no conflict of interest.

\section{REFERENCES}

Ahn EM, Myung NY, Jung HA, Kim SJ. The ameliorative effect of Protaetia brevitarsis Larvae in HFD-induced obese mice.
Food Science and Biotechnology. 2019. 28: 1177-1186.

Beutler B. Tlr4: central component of the sole mammalian LPS sensor. Current Opinion in Immunology. 2000. 12: 20-26.

Birrell MA, Hardaker E, Wong S, McCluskie K, Catley M, De AJ, Newton R, Haj-Yahia S, Pun KT, Watts CJ, Shaw RJ, Savage TJ, Belvisi MG. Ikappa-B kinase-2 inhibitor blocks inflammation in human airway smooth muscle and a rat model of asthma. American Journal of Respiratory and Critical Care Medicine. 2005. 172: 962-971.

Edwards MR, Strong K, Cameron A, Walton RP, Jackson DJ, Johnston SL. Viral infections in allergy and immunology: How allergic inflammation influences viral infections and illness. The Journal of Allergy and Clinical Immunology. 2017. 140: 909-920.

Fedenko ES, Elisyutina OG, Filimonova TM, Boldyreva MN, Burmenskaya OV, Rebrova OY, Yarilin AA, Khaitov RM. Cytokine gene expression in the skin and peripheral blood of atopic dermatitis patients and healthy individuals. Self Nonself. 2011. 2: 120-124.

Guo H, Callaway JB, Ting JP. Inflammasomes: mechanism of action, role in disease, and therapeutics. Nature Medicine. 2015. 21: 677-687.

Han NR, Moon PD, Kim NR, Kim HY, Jeong HJ, Kim HM. Schisandra chinensis and Its Main Constituent Schizandrin Attenuate Allergic Reactions by Down-Regulating Caspase1 in Ovalbumin-Sensitized Mice. The American Journal of Chinese Medicine. 2017. 45: 159-172.

Kim SJ, Kim MC, Um JY, Hong SH. The beneficial effect of vanillic acid on ulcerative colitis. Molecules. 2010. 15: 7208 $-7217$.

Kuida K, Lippke JA, Ku G, Harding MW, Livingston DJ, Su MS, Flavell RA. Altered cytokine export and apoptosis in mice deficient in interleukin-1B converting enzyme. Science. 1995. 267: 2000-2002.

Lee YS, Han SB, Ham HJ, Park JH, Lee JS, Hwang DY, Jung YS, Yoon DY, Hong JT. IL-32 $\gamma$ suppressed atopic dermatitis through inhibition of miR-205 expression via inactivation of nuclear factor-kappa B. Journal of Allergy and Clinical Immunology. 2020. 146: 156-168.

Liu YC, Zou XB, Chai YF, Yao YM. Macrophage polarization in inflammatory diseases. International Journal of Biological Sciences. 2014. 10: 520-529.

Liu Y, Duan C, Chen H, Wang C, Liu X, Qiu M, Tang H, Zhang F, Zhou X, Yang J. Inhibition of COX-2/mPGES-1 and 5-LOX in macrophages by leonurine ameliorates monosodium urate 
crystal-induced inflammation. Toxicology and Applied Pharmacology. 2018. 15; 351: 1-11.

Rumzhum NN, Ammit AJ. Cyclooxygenase 2: its regulation, role and impact in airway inflammation. Clinical \& Experimental Allergy. 2016. 46: 397-410.

Shin WB, Dong X, Kim YS, Park JS, Kim SJ, Go EA, Kim EK, Park PJ. Anti-inflammatory Effects of Batillaria multiformis Water Extracts via NF- $\mathrm{kB}$ and MAPK Signaling Pathways in LPS-Induced RAW 264.7 Cells. Advances in Experimental Medicine and Biology. 2019. 1155: 1001-1014.

Siegmund B, Lehr HA, Fantuzzi G, Dinarello CA. IL-1 beta converting enzyme (caspase-1) in intestinal inflammation. Proceedings of the National Academy of Sciences of the United States of America. 2001. 98: 13249-13254.

Sultuybek GK, Soydas T, Yenmis G. NF-kB as the mediator of metformin's effect on ageing and ageing-related diseases. Clinical and Experimental Pharmacology and Physiology. 2019. 46: 413-422.

Trefzer U, Hofmann M, Sterry W, Asadullah K. Cytokine and anticytokine therapy in dermatology. Expert Opinion on Biological Therapy. 2003. 3: 733-743.

Van Huis A. Edible insects are the future? Proceedings of the Nutrition Society. 2016. 75: 294-305.
Van Itterbeeck J, van Huis A. Environmental manipulation for edible insect procurement: a historical perspective. Journal of Ethnobiology and Ethnomedicine. 2012. 8: 3.

Wicks IP, Roberts AW. Targeting GM-CSF in inflammatory diseases. Nature Reviews Rheumatology. 2016. 12: 37-48.

Wong CK, Ho CY, Ko FW, Chan CH, Ho AS, Hui DS, Lam CW. Proinflammatory cytokines (IL-17, IL-6, IL-18 and IL-12) and Th cytokines (IFN-gamma, IL-4, IL-10 and IL-13) in patients with allergic asthma. Clinical and Experimental Immunology. 2001. 125:177-183.

Yoo YC, Shin BH, Hong JH, Lee J, Chee HY, Song KS, Lee KB. Isolation of fatty acids with anticancer activity from Protaetia brevitarsis larva. Archives of Pharmacal Research. 2007. 30: 361-365.

https://doi.org/10.15616/BSL.2020.26.4.267

Cite this article as: Myung NY, Ahn EM, Kim SJ. The Anti-inflammatory Mechanism of Protaetia brevitarsis Lewis via Suppression the Activation of NF- $\kappa \mathrm{B}$ and Caspase-1 in LPS-stimulated RAW264.7 Cells. Biomedical Science Letters. 2020. 26: 267-274 